УДК 8

DOI 10.31483/r-21844

\title{
Г.А. Соколова
}

\section{СИМВОЛИЧЕСКОЕ ЗНАЧЕНИЕ ЛЕСА В НЕМЕЦКОЙ СКАЗКЕ}

Аннотация: в данной статье предпринимается попытка проследить, как формировалось и как менялось восприятие леса в немецком языковом пространстве, особое внимание уделяется символическому толкованию леса, дается объяснение, что символизируют некоторые породы деревьев, показывается связь леса с символикой женского начала. В работе также рассматривается восприятие леса в произведениях романтиков, приводятся примеры из немецких романтических сказок братьев Гримм, местом действия в которых является лес. Примечательно, что названия некоторых сказок братьев Гримм связано с деревом или лесом.

Ключевые слова: лес, дерево, липа, дуб, символ, восприятие, языковое пространство, сказка, романтизм.

\section{G.A. Sokolova}

\section{THE SYMBOLIC MEANING OF THE FOREST IN THE GERMAN FAIRY-TALE}

Abstract: this article attempts to show how the perception of the forest in the German language space was built and how it changed. It especially focuses on the symbolic interpretation of the forest, explains what some tress symbolize and shows the connection of the forest with the symbolism of the feminine. The article also deals with the perception of the forest in the works by romantic writers and provides examples from some romantic fairy-tales by the Brothers Grimm where the action takes place in the forest. It is worth mentioning that the titles of some fairy-tales by the Brothers Grimm are connected with the tree or with the forest.

Keywords: forest, tree, linden, oak, symbol, perception, language space, fairytale, romanticism. 
В религиозных представлениях и людских поверьях многих народов лес всегда играл важную роль и символизировал священный таинственный мир, в котором существуют добрые и злые боги, духи, демоны, феи. Упоминание о священной роще, в которой можно найти убежище и приют, встречается во многих культурах мира. Лес становится местом действия в различных фольклорных произведениях [1, с. 322-323].

В языческой религии древних важное место занимал культ священных деревьев. Поклонение священным деревьям основывалось на вере в то, что в них обитают «древесные духи». Стараясь задобрить духов священных деревьев, совершались жертвоприношения [5, с. 120].

Как известно, до наступления средневековья леса покрывали практически всю центральную Европу. На территории Германии произростал смешанный лес, были распространены дуб, липа и ясень. В представлении немцев лес долгое время был темным, мрачным и опасным местом, пристанищем демонов и других злых сказочных существ. Однако древние германцы почитали деревья и посвящали их разным богам. Так, например, липа ассоциировалась с богиней любви Фрейи. Липа считалась деревом мягкой породы из-за липового сока. В Германии это дерево также было символом женской нежности, мягкости, грации и красоты [5, с. 126].

Липа также наделялось лечебными свойствами, т.к. германцы верили, что при прикосновении липа притягивает болезни человека на себя. Считалось, что липа могла уберечь от молний [1, с. 172].

Дуб считался священным деревом в представлении многих индогерманских народов. Как известно, в Древней Греции дуб был посвящен Зевсу, в Древнем Риме - Юпитеру, германцы посвящали его богу-громовержцу Донару, который также носил имя Тор, прежде всего из-за величественного образа дуба и его свойства притягивать молнии [1, с. 64-65].

Из-за крепкой древесины дуб со времен античности символизировал силу, мужество, упорство. Его древесина считалась нетленной, поэтому дуб также был символом бессмертия. Дубовые рощи относились к культовым центрам, где 
совершались различные обряды. В священных рощах и полесьях совершались жертвоприошения богам [1, с. 65].

В северогерманском языковом пространстве была распространена идея о существовании Мирового Древа, axis mundi, связывающего небо, землю и подземный мир. Мировое Древо скандинавов красочно описано в «Старшей Эдде». Гигантский ясень Иггдрасиль соединяет девать миров. Вечнозеленое Древо Жизни пропитано священным живительным медом. На его вершине сидят старый мудрый орел и ястреб Ведрфельнир, а корни дерева гложут дракон и змеи. По стволу бегает белка Рататоск, своеобразный посредник между ними. Три корня Иггдрасиля простираются к миру людей, великанов и в Царство Мертвых. Под корнями чудесного ясеня находятся три источника: Урд («Судьба»), Хвергельмир («Кипящий Котел») и медовый источник мудрости Мимира [5, с. 120].

С приходом христианства миф о священных деревьях был разрушен. Деревья стали воспринимать как языческих идолов, которых надо было уничтожить. Некоторые миссионеры предпиняли попытку превратить языческие святыни в христианские. Отныне липа была посвящена не богине Фрее, а Деве Марии, матери Иисуса Христа. Однако это не изменило представление немцев о лесе как о нечто темном, преступном, мрачном. Эта идея распространилась за пределы германского пространства.

Приблизительно в 100 году нашей эры древнеримский историк Корнелий Тацит в этнографическом описании «О происхождении германцев и местоположении Германии» изобразил германские леса жуткими и зловещими, болота омерзительными и страшными. Это полностью соответствовало реальности: в те времена германские леса населяли дикие животные, путников также подстерегали разбойники.

Такая картина мрачного леса надолго закрепилась в умах германцев. Как отмечают исследователи, именно в немецком языковом пространстве лес изображался всегда таинственным и мрачным. В средние века эта идея получила большее развитие. Лес ассоциировался с обителью демонов, жутких сказочных существ и изображался таковым в разных легендах и сказках [1, с. 323]. 
В сказках, как и в средневековой рыцарской поэзии, герой или героиня растут в лесу. Они попадают в лес, где находят чудесные травы и зверей или неведомых существ, владеющих магическими способностями. Лес, который в прошлом покрывал большую часть территории многих стран, в сказках является отображением мира, куда герой отправляется в поисках тайн и их раскрытия. Лес всегда полон опасностей, но тот, кто «хочет идти своим путем», познает в нем и жизненные радости. Когда сказочный герой преодолевает лес, он находит любимую, с которой обретает счастье. Так выглядит схема, по которой строятся сюжеты многочисленных сказок [4, с. 212-214].

В сказочном лесу герои народных преданий встречают таинственное существо - лесную женщину, ведьму, ее служанок или дочерей. Эта встреча оказывается решающей в их дальнейшей судьбе. Примечательно, что во многих сказках народов, принадлежащих к индоевропейской семье языков, обнаруживается полное совпадение существ и языкового обращения с ними. Так имя «госпожи Холле», как называют это загадочное женское существо в немецких сказках, которой в северо-германской «Эдде» соответствует богиня подземного мира Хель, возводят к значению греческого именя «калиптейн», что означает «verhüllen» («заволакивать», «окутывать»). Индийская богиня рождения Бхавани может превращаться в сеющую смерть Кали. Злата-Баба может превращаться в ЯгуБабу [4, с. 222-223].

По мнению некоторых исследователей, лес связан с символикой женского начала. Он является символом земли и противопоставляется власти солнца. Лес место всевозможной опасности, подвластное духам, демонам. Лес - традиционное место, где можно заблудиться. Затерявшимися в лесу оказываются герои волшебных сказок, которым предстоит пройти много испытаний [3, с. 280-281].

В реальности отношение к лесу не было позитивным. В XVII веке в связи с развитием промышленных отраслей начинают вырубать лес. Это наносит большой урон природе. В начале XVIII века Ганс Карл Карловитц впервые формулирует мысль о том, что взамен срубленному дереву должно быть посажено новое. Однако его слова не найдут поддержки у большего числа населения. Пока лес 
рассматривался как основной вид топлива для промышленных отраслей, его вырубка продолжалась.

В духовной сфере начинаются изменения в XIX веке. С приходом романтизма в начале XIX века отношение немцев к лесу меняется радикально. В своих работах романтикам удалось создать душевный пейзаж, лес стал символизироваться с желанным, священным и заветным миром. Романтическое восприятие леса возникло в городской интеллектуальной среде. Расширение городов, начинающийся процесс индустриализации вызвал у многих горожан чувство потери связи с природой, местом, где можно отдохнуть, помечтать. Лес стал таким идеальном местом, куда можно было сбежать от городской суеты.

Примечательно, что действие во многих сказках братьев Гримм происходит в лесу, например, в таких произведениях, как: «Гензель и Гретель» («Hänsel und Gretel»), «Красная Шапочка» («Rotkäppchen»), «Белоснежка» («Schneewittchen»). Названия некоторых сказок также связано с деревом, например, «Сказка о заколдованном дереве» («Der Zauberbaum»), «Старец в лесу» («Der Alte im Wald»), «Три зеленые ветви» («Die drei grünen Zweige»), «Ветка орешника» («Die Haselrute»), «Лесной дом» («Das Waldhaus»), «Три маленьких лесовика» («Die drei Männlein im Walde»). Многие сказки содержат упоминание о лесе. Это может быть сообщение пространственных координат, как в сказке «Король-лягушонок и Железный Генрих» («Der Froschkönig oder der eiserne Heinrich»): «Nahe bei dem Schloss des Königs lag ein großer dunkler Wald, und in dem Walde unter einer alten Linde war ein Brunnen» [2, c. 12]. Лес около замка короля представлен темным, а липа в нем старой. В лесу могут жить сказочные персонажи, как в сказке «Ребенок Девы Марии» («Marienkind»): «Vor einem großen Walde lebte ein Holzhacker mit seiner Frau» [2, с. 18]. Лес может быть изображен как открытое пространство, таящее в себе опасности, в которой попадают сказочные персонажи из защищенного закрытого пространства домашнего очага, например, в сказке «Волк и семеро козлят» («Der Wolf und die sieben jungen Geißlein»): «Eines Tages wollte sie in den Wald gehen und Futter holen» [2, c. 32]. 
Стоит заметить, что у простых людей вначале не было «романтического» восприятия леса. Они относились к нему как к месту, где можно было «добыть» природные ресурсы (ягоды, древесину и т. д.). Лишь к концу XIX века их отношение изменилось, и они стали воспринимать лес как место, где отдыхает душа.

В это время происходит увеличение темпа индустриализации, на нужды которой начинают вырубать леса, в противовес этому начинает активно развиваться лесничество. Ситуация меняется в XX веке, когда в 30-е годы большое внимание начинают уделять охране природных ресурсов, в том числе лесных массивов. Однако это время охарактеризовалось символическим восприятием леса, когда для посадки выбирали определенные виды деревьев, среди которых особое распространение получил дуб.

В наши дни одна треть площади Германии покрыта лесами, однако многовековых деревьев практически не осталось. Отношение немцев к лесу по-прежнему бережное. Их любовь к порядку проявляется и в «лесном» вопросе. Регулярно производится подсчет деревьев, рассматриваются зоны распространения конкретных пород деревьев: елей, сосен, буков. Средний возраст немецкого дерева составляет 77 лет. Сейчас лес ассоциируется с красотой природы, воспетой романтиками, а также местом, где можно восстановить здоровье благодаря спортивным занятиям.

\section{Список литературы}

1. Becker U. Lexikon der Symbole.- Köln: KOMET Verlag GmbH, 2008. 352 c.

2. Brüder Grimm. Die Kinder- und Hausmärchen. - М.: Радуга, 2003. - 288 с.

3. Андреева В. Энциклопедия. Символы, знаки, эмблемы / В. Андреева, В. Куклев, А. Ровнер. - М.: Астрель; АСТ, 2006. - 556 с.

4. Бауэр В., Дюмотц И., Головин С. Энциклопедия символов. - М.: КронПреcс, 2000. - 504 c.

5. Вовк О.В. Энциклопедия знаков и символов. - М.: Вече, 2006. - 528 с. 


\section{References}

1. Becker U. Encyclopaedia of Symbols. - Cologne: KOMET Publishing House GmbH, 2008. -352 p.

2. The Brothers Grimm. The Childrens' and Household Tales. - M.: Open Society Publishing House «Raduga», 2003. - 288 p.

3. Andreeva V. Encyclopaedia. Symbols, Signs, Emblems / V. Andreeva, V. Kuklev, A. Rovner. - M.: Astrel: AST, 2006. - 556 p.

4. Bauer V. Encyclopaedia of Symbols / V. Bauer, I. Dumotz, S. Golovin. - M.: Kron-Press, 2000. -504 p.

5. Vovk O. Encyclopaedia of Signs and Symbols. - M.: Veche, 2006. - 528 p.

Соколова Галина Александровна - канд. филол. наук, доцент ФГБОУ ВО «Московский государственный лингвистический университет», Россия, Москва.

Sokolova Galina Aleksandrovna - candidate of philological sciences, associate professor at the Moscow State Linguistic University, Russia, Moscow. 